\title{
Fome e Prosperidade Econômica na América
}

\author{
The Paradox of Hunger and \\ Economic Prosperity in America, J. \\ Larry Brown and Stanley N. \\ Gershoff. J. Publ. Hl th Policy, \\ 10: $425-443,1989$.
}

* Professor Titular da Escola Nacional de Saide Pública/Fio. cruz
(1) Ver: Análise de um documento, "Hunger in America, the Growing Epidemic". Cadernos de Saúde Pública, i: 359-371, 1985.

(2) U.S. Conference of Mayors, Hunger in American Cities, Washington, DC, 1983 Cit. Jil. Brown \& S. N. Gershoff.
Frederico Simōes Barbosa*

Uma análise crítica sobre a situaçâo da pobreza e da fome no período de 1977 a 1986 foi feita por $J$. Larry Brown et alii, nos EUA. Os autores indicam que as causas subjacentes deste fenômeno repousam sobre o aumento da desigual distribuição da riqueza naquele pais e do enfraquecimento dos programas federais de assistência aos pobres. Comentários de outros sugerem que as causas mais profundas deste fenômeno têm raizes estruturais.

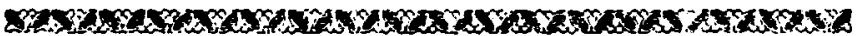

Dando continuidade a seus estudos sobre a fome e a pobreza nos EUA, os autores do artigo acima fazem uma análise histórica e crítica sobre a situação da economia e da saúde naquele país, a partir de 1967. quando o Congresso americano manifestou-se, vigorosamente, a favor de programas nacionais de combate à fome.

Dez anos depois da criação dos conhecidos programas de amparo às minorias destituídas e grupos de risco, a situação havia melhorado, substancialmente, embora grupos vivendo abaixo do nível de pobreza ainda existissem.

A partir de então, a fome passou despercebida até que, em 1982, surgiu, bruscamente, no cenário da saúde pública, em forma considerada epidêmica (1).

Advertências de várias origens foram feitas, valendo mencionar a Conferência Bipartidária de Prefeitos, reunida em 1983, na qual a fome foi considerada "a most serious emergency" (2).

Através de extenso número de referências, os autores analisam a situação daquele País, de 1977 a 1986, mostrando que os setores de economia foram Cadernos de Saúde Pública, RJ, 6(2): 154-157, abr/jun, 1990 
substancialmente alterados, aumentando a desigual distribuiçāo de renda. Apesar disso, foi possível ao País sustentar seu crescimento econômico, mesmo quando substancial parte da população decaía economicamente em relação ao setor dos que ganhavam mais.

Segundo os autores, ficou rompida a tradicional associação entre desemprego e pobreza. Os índices de pobreza não acompanharam os níveis de desemprego, quando comparados aos níveis pré-recessionais. Assim, os elevados índices de emprego não levaram à redução da pobreza.

A tabela I mostra os níveis de desemprego e os de pobreza, por grupos raciais. Observe-se que, enquanto a pobreza entre os negros não parece ter mudado significantemente, o mesmo não aconteceu com os outros segmentos da população. O aumento da pobreza entre os brancos e os hispânicos foi acentuado.

\section{TABELA I}

Desemprego e Índices de Pobreza, 1977 x 1986

\begin{tabular}{lrr}
\hline & 1977 & 1986 \\
\hline Índice de Desemprego & $7,1 \%$ & $7,0 \%$ \\
Índice de Pobreza & $11,6 \%$ & $13,6 \%$ \\
Brancos & $8,9 \%$ & $11,0 \%$ \\
Negros & $31,3 \%$ & $31,1 \%$ \\
Hispânicos & $22,4 \%$ & $27,3 \%$ \\
N: Pessoas Pobres & 24.720 .000 & 32.370 .000 \\
N: Crianças Pobres & 10.288 .000 & 12.876 .000 \\
\hline
\end{tabular}

Fonte: US Bureau of the Census, Washington, DC, 1987.

Embora o desemprego tenha declinado nos anos recentes, os índices de pobreza não acompanharam esta queda como aconteceu nos anos anteriores. Isto ocorreu embora uma maior proporção de adultos pobres (de 15 anos e mais) estejam hoje empregados - cerca de $41,5 \%$ - do que em qualquer época, nos últimos vinte anos. Cerca de 2,3 milhões mais de pessoas pobres estão trabalhando, hoje, do que há uma década atrás. Esta maior proporção de pessoas pobres trabalhando não reflete maior número de jovens empregados entrando no mercado de trabalho, mas envolve, largamente, chefes de família, cujo baixo poder aquisitivo afeta os outros membros de suas famílias (3). 
Número de famílias pobres que não seriam pobres se os programas assistenciais fossem tão efetivos quanto o foram em 1979

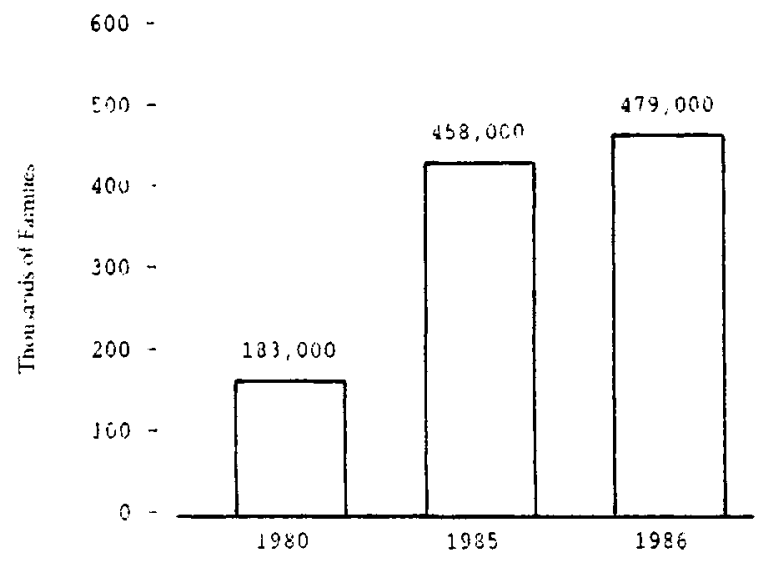

Fonte: Centro de Orçamento e Prioridades Políticas. Washington, DC, US Census Bureau, 1986.

Enquanto milhões de famílias têm ingresso anual abaixo do nível de pobreza, milhões de outros americanos vivem nos limites de pobreza. Cerca de 13,6\% da população viveram em pobreza, durante todo 0 ano, enquanto cerca de $25 \%$ viveram em pobreza, durante algum tempo do ano.

Os autores aceitaram o fato de que a nação rica, em seu sexto ano de crescimento econômico, está convivendo com acentuada pobreza de grande parte de sua população. Isto reflete seu crescimento desequilibrado e é, segundo os autores, resultado do enfraquecimento dos programas federais de assistência aos pobres.

Os autores concluem: "The diminishing effectiveness of weakened federal programs, changing patterns of employment, and sharp wage reductions in the country, are associated with the virtually unprecedented paradox of widespred domestic hunger at a time of national economic prosperity".

$\mathrm{O}$ artigo analisado limita-se aos aspectos conjunturais do fenômeno: a fome nos EUA.

Vale, assim, recolocar alguns comentários feitos na análise publicada, anteriormente, sobre este mesmo 
assunto (4), quando um dos comentadores assinala (5): "Se o problema subjacente da pobreza e da fome está (como parece implícito em vários textos do documento) ligado à má distribuição de renda nacional, as modificaçōes a operar terão de atingir, profundamente, as raízes estruturais da economia do país. Alguns podem interpretar estes dados como inevitável tragédia burguesa da conjuntura atual dos EUA que será corrigida com o tempo e o idealismo do povo americano. Outros, uma minoria sem dúvida, como inaceitável distorçâo estrutural nos campos social, econômico e político do Pais".

Outro comentarista (6) do documento acima citado refere: "A reflexão em torno do significado desses 20 milhões de famintos cidadãos da mais rica naçâo do mundo não se esgota ao nível das questões conjunturais. Ela deve, necessariamente, contemplar questóes de perspectiva temporal mais ampla, tais como avaliar o impacto da 3: Revolução Industrial, ora em curso, sobre essa legião de excluídos. A questão da fome, agora endêmica nos EUA, deve ser pensada não só no quadro de uma repartição crescentemente desigual dos frutos do progresso técnico, mas também no quadro de um processo de desagregação social, ao qual o desenvolvimento do capitalismo não está infenso."

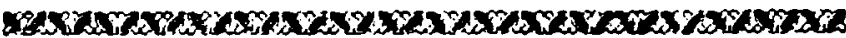

A critical analysis made on the current status (1977) to 1986) of the poverty and hunger in the USA is presented by J. Larry Brown et alii. The main conclusion is that the phenomenon is linked to the inequal national wealth distribution and the less emphasis given to the federal assistencial programs. Comments by others indicate that the phenomenon has deep economic structural roots.

(4) Op. Cit. Cademos de Saúde Pública, 1: 359-371, 1985.

(5) F. S. Barbosa

(6) G. E. M. Kornis 